\title{
Bacillus farraginis sp. nov., Bacillus fortis sp. nov. and Bacillus fordii sp. nov., isolated at dairy farms
}

Correspondence

Patsy Scheldeman

P.Scheldeman@clo.fgov.be

\author{
Patsy Scheldeman, ${ }^{1}$ Marina Rodríguez-Díaz, ${ }^{2}$ Johan Goris, ${ }^{1,3} \dagger$ \\ Annelies Pil, ${ }^{1,3}$ ‡ Elke De Clerck, ${ }^{3}$ Lieve Herman, ${ }^{1}$ Paul De Vos, ${ }^{3}$ \\ Niall A. Logan ${ }^{2}$ and Marc Heyndrickx ${ }^{1}$
}

\author{
${ }^{1}$ Ministry of the Flemish Community, Centre for Agricultural Research, Department of Animal \\ Product Quality, Brusselsesteenweg 370, 9090 Melle, Belgium \\ ${ }^{2}$ Glasgow Caledonian University, School of Biological and Biomedical Sciences, Cowcaddens \\ Road, Glasgow G4 OBA, UK \\ ${ }^{3}$ Ghent University, Faculty of Sciences, Laboratory of Microbiology (WE10), K. L. \\ Ledeganckstraat 35, 9000 Gent, Belgium
}

\section{INTRODUCTION}

Milk is a highly nutritious substrate that can support the growth of a wide variety of both Gram-negative and Gram-positive bacteria (Ternström et al., 1993; Griffiths \& Philips, 1990). Aerobic spore-forming bacteria of the genus Bacillus and related genera are commonly present in raw milk (Waes, 1976; Crielly et al., 1994; McGuiggan et al., 2002). Owing to their natural resistance properties, spores can survive during food processing. After germination and outgrowth to high levels, they may cause spoilage and even outbreaks of food-borne illness. They have been responsible for adversely affecting the quality of pasteurized milk and milk products (Guirguis et al., 1983; Meer et al., 1991) and ultra heat-treated (UHT) products (Hammer et al., 1995). Highly heat resistant spores of Bacillus sporothermodurans were detected in UHT products in

Published online ahead of print on 9 February 2004 as DOI 10.1099/ijs.0.63095-0.

tPresent address: Center for Microbial Ecology, Michigan State University, 540 Plant \& Soil Science Building, East Lansing, MI 48824-1325, USA. $\ddagger$ Present address: Department of Bacteriology and Immunology, Veterinary and Agrochemical Research Centre, VAR-CODA-CERVA, Groeselenberg 99, 1180 Ukkel, Belgium.

Abbreviations: FAME, fatty acid methyl ester; rep-PCR, repetitive element sequence-based PCR; UHT, ultra heat treated.

The GenBank accession numbers for the $16 \mathrm{~S}$ rRNA gene sequences of $B$. farraginis R-8039, R-6538, R-6540 ${ }^{\top}$ and R-6915, B. fortis R-6514 ${ }^{\top}$ and B. fordii R-7190 are AY443034-AY443039, respectively.

Details of DNA-DNA hybridization results and photomicrographs of sporangia and vegetative cells of the type strains of $B$. farraginis, $B$. fortis and B. fordii are available as supplementary material in IJSEM Online. 
different countries both inside and outside Europe (Guillaume-Gentil et al., 2002).

The presence of B. sporothermodurans spores in feed concentrate, silage, soy and pulp was demonstrated for individual dairy farms (de Silva et al., 1998; Vaerewijck et al., 2001; Scheldeman et al., 2002). In order to prevent contamination of milk and dairy products with aerobic spore-forming bacteria, it is important to ensure that contamination of raw milk is minimized. To achieve this, the nature and origin of spores and in particular of spores with a potential high heat resistance in raw milk must be better understood. In a survey of dairy farms, several strains were isolated from raw milk, the milking apparatus and animal feeds after $30 \mathrm{~min}$ heat treatment at $100{ }^{\circ} \mathrm{C}$, as a selection procedure for spore-forming bacteria with potential high heat resistance (Scheldeman et al., 2002).

In this study, we elucidated the taxonomic positions of 48 potentially highly heat-resistant isolates from different sources at dairy farms. In addition to molecular typing, we used extensive phenotypic characterization as well as $16 \mathrm{~S}$ rRNA gene sequence determinations and whole-genome hybridization studies to group and to identify these strains.

\section{METHODS}

Strains and culture conditions. Details of the strains included in this study are listed in Table 1. All strains were isolated after $30 \mathrm{~min}$ heat treatment at $100{ }^{\circ} \mathrm{C}$ of samples taken at dairy farms (Scheldeman et al., 2002). All isolates were grown on brain heart infusion (BHI) (Oxoid) supplemented with bacteriological agar no. 1 (Oxoid) and filter-sterilized vitamin $\mathrm{B}_{12}\left(1 \mathrm{mg} \mathrm{l}^{-1}\right)$ (Sigma).

DNA preparation. Whole-cell DNA for PCR amplification was extracted from pure cultures by the method described by Pitcher et al. (1989). For DNA-DNA reassociation experiments, high-quality total genomic DNA was purified using a modification of the method described by Gevers et al. (2001), as outlined by De Clerck et al. (2004).

rep-PCR genomic fingerprinting. The conditions for genomic fingerprinting by means of repetitive element sequence-based PCR (rep-PCR), directed against the REP (repetitive extragenic palindromic) element or the $(\mathrm{GTG})_{5}$ repetitive sequence, were previously described by Herman et al. (1998). The (GTG) 5 primer (Versalovic et al., 1994) was used under the following PCR conditions. Amplification reactions were performed in a final volume of $25 \mu$ l containing PCR buffer ( $10 \mathrm{mM}$ Tris/ $\mathrm{HCl}, \mathrm{pH} 8 \cdot 3$, and $50 \mathrm{mM} \mathrm{KCl)} \mathrm{(Applied}$ Biosystems), $1.5 \mathrm{mM} \mathrm{MgCl} 2,0 \cdot 2 \mathrm{mM}$ of each dNTP (Pharmacia), $0 \cdot 3 \mu \mathrm{g}$ primer (Isogen), $1 \mathrm{U}$ Goldstar DNA polymerase (Eurogentec) and $25 \mathrm{ng}$ DNA template. The PCR program (Versalovic et al., 1994) was run on a DNA thermal cycler (Perkin Elmer 9600). To avoid inter-PCR differences, all samples were included in one single PCR run.

The rep-PCR amplicons, obtained with the REP- and (GTG) primers, were separated on a $1.5 \%$ LSI LE agarose gel (Life Science International) $(20 \times 25 \mathrm{~cm})$ for $4 \mathrm{~h}$ at a constant voltage of $4 \mathrm{~V} \mathrm{~cm}^{-1}$ in $1 \times$ TBE $(100 \mathrm{mM}$ Tris/ $\mathrm{HCl}, 100 \mathrm{mM}$ boric acid, $2 \mathrm{mM}$ EDTA, $\mathrm{pH} 8 \cdot 0$ ). The rep-PCR profiles were visualized after staining with ethidium bromide, followed by digital image capturing using a GelDoc 2000 camera (Bio-Rad). A mixture of molecular mass markers VIII, IX and X (Roche) was used as reference for intra- and inter-gel comparison. Numerical analysis of the resulting fingerprints was performed using the GELCOMPAR II version 2.0 software package (Applied Maths). The similarity among digitized profiles was calculated using Pearson's correlation coefficient and an average linkage (UPGMA) dendrogram was derived.

Whole-cell protein profiling. Cells used for whole-cell protein profiling through SDS-PAGE analysis were obtained after $24 \mathrm{~h}$ of growth on NAG (nutrient agar supplemented with $1 \%$ glucose, $\mathrm{pH} 7 \cdot 4$ ). SDS protein extracts were prepared and electrophoresed according to Pot et al. (1994). Data collection and interpretation were conducted as described by Vauterin \& Vauterin (1992).

$16 S$ rDNA sequencing and phylogenetic analysis. The $16 \mathrm{~S}$ rRNA genes of strains R-6514 ${ }^{\mathrm{T}}$, R-6521, R-6538, R-6540 ${ }^{\mathrm{T}}$, R-6915 and $\mathrm{R}-7190^{\mathrm{T}}$ were amplified by PCR using conserved primers pA (5'-AGAGTTTGATCCTGGCTCAG- $\left.3^{\prime}\right)$ and $\mathrm{pH}$ (5'-AAGGAGGTGATCCAGCCGCA- $\left.3^{\prime}\right)$. The PCR products were purified and subsequently sequenced using an ABI 310 Sequencer (Applied Biosystems) as previously described (Scheldeman et al., 2002). A combination of the primers given by Coenye et al. (1999) was used to obtain a continuous stretch of the 16S rRNA gene sequence. Sequence assembly was implemented using the GENEBASE software (Applied Maths). The BIONUMERICS 3.0 software package (Applied Maths) was used for construction of a phylogenetic tree based on the neighbour-joining method.

DNA-DNA reassociation experiments. DNA-DNA hybridizations were performed at $37^{\circ} \mathrm{C}$ with photobiotin-labelled probes in microplate wells according to the method of Ezaki et al. (1989), using an HTS7000 Bio Assay Reader (Perkin Elmer) for the fluorescence measurements as described in detail by Willems et al. (2001).

DNA G+C content. The DNA base composition was determined by HPLC using further specifications given by Logan et al. (2000).

Fatty acid analysis. The culture conditions for fatty acid methyl ester (FAME) analysis were as described by Scheldeman et al. (2002). The methods used for fatty acid extraction, methyl ester preparation and separation by gas chromatography were as described by Vancanneyt et al. (1996).

Physiological and morphological characterization. Phenotypic tests were performed as described by Logan \& Berkeley (1984) and Heyrman et al. (2004); other characters were determined and the data analysed numerically using the general similarity coefficient of Gower $\left(S_{\mathrm{G}}\right)$ as described by Logan et al. (2000). For observations on sporangia, cells were grown on tryptic soy agar (TSA) supplemented with $5 \mathrm{mg} \mathrm{MnSO}_{4} \mathrm{I}^{-1}$ at $30^{\circ} \mathrm{C}$. Tests for assimilation of substrates as the sole carbon source were performed following the methods described by Heyndrickx et al. (1997).

\section{RESULTS AND DISCUSSION}

\section{Grouping based on whole-cell protein and genomic profiling}

To assess the diversity in the collection of 48 potentially highly heat-resistant spore-forming strains from dairy farms, two genome-based molecular fingerprinting methods were applied together with whole-cell protein profiles (SDSPAGE). The result of a numerical analysis based on wholecell protein profiles is summarized in Table 1. Three clusters could be delineated with an internal similarity of at least $90 \%$. The 32 strains grouping together in cluster A (and accordingly denominated in Table 1) mainly 
Table 1. Details of the origin of Bacillus strains used in this study

Culture collection abbreviations: R, Research collection of the BCCM/LMG Bacteria Culture Collection, Gent, Belgium; MB, Culture Collection, Molecular Bacteriology Laboratory of the Department of Animal Product Quality, Melle, Belgium.

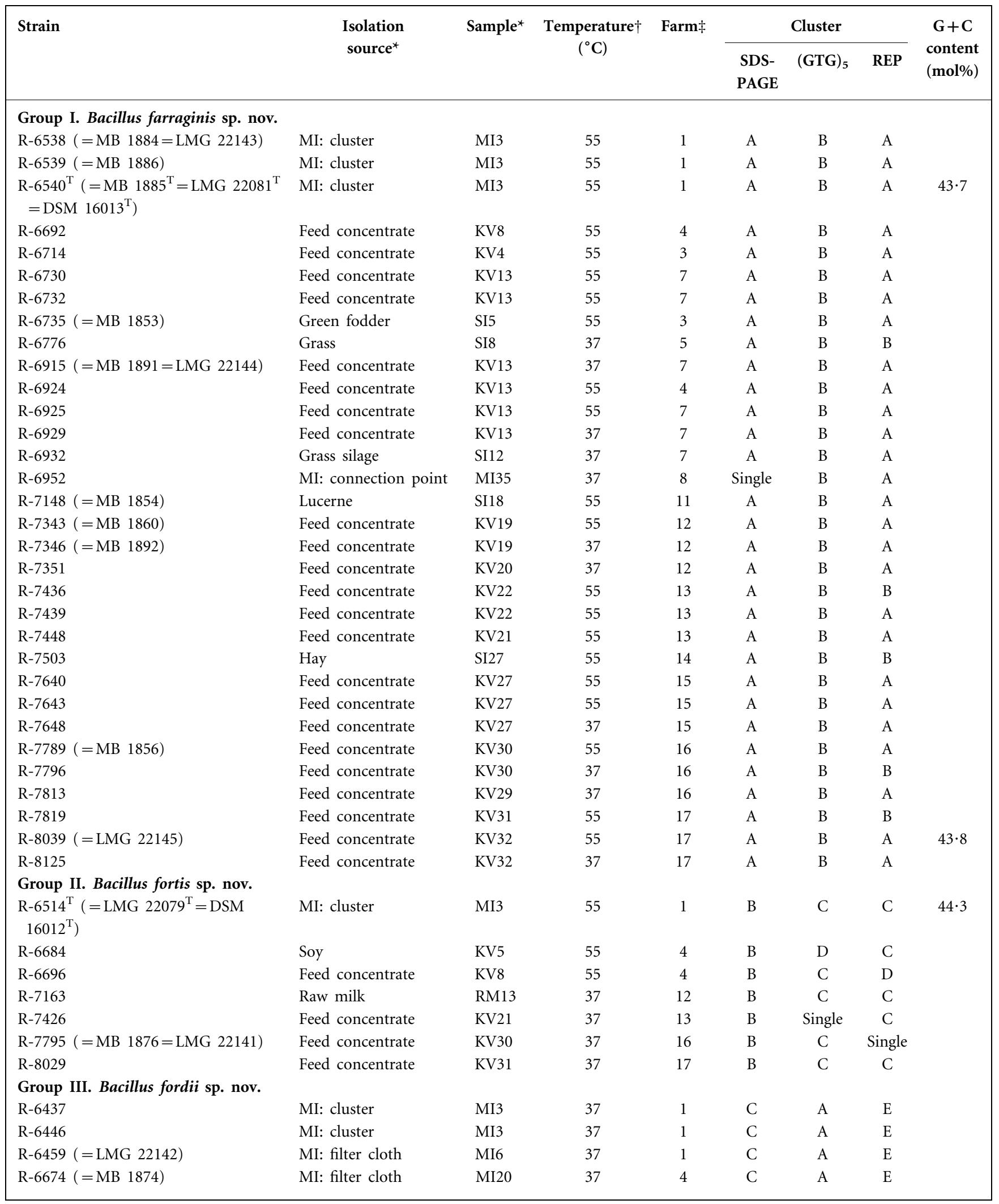


Table 1. cont.

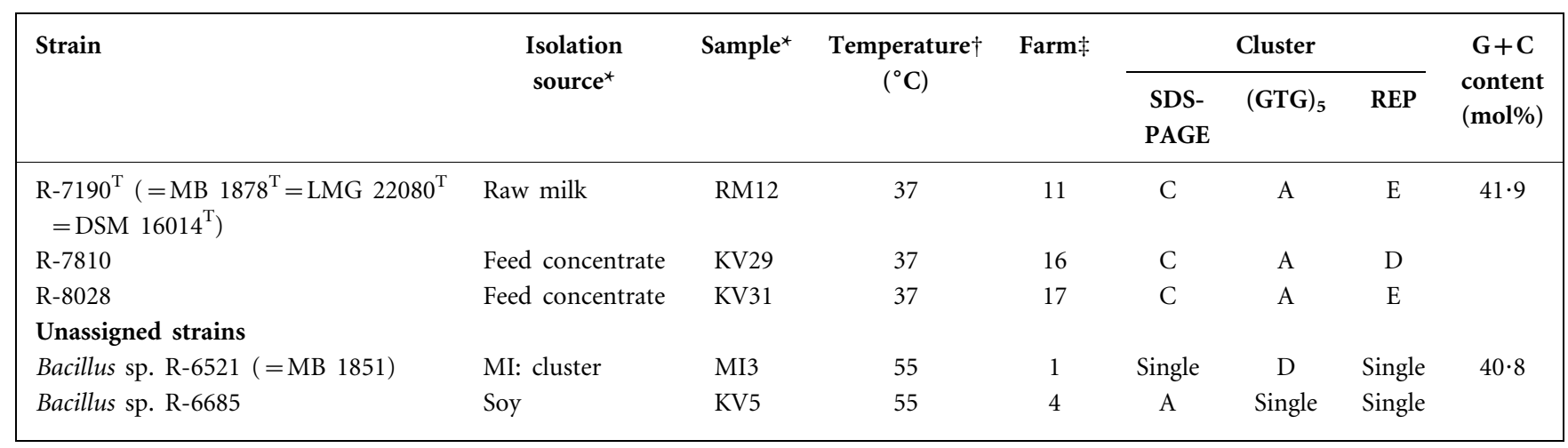

${ }^{\star}$ MI, Milking apparatus; KV, cattle feed; SI, green fodder; RM, raw milk.

$\dagger$ Temperature of isolation, temperature used for incubation following heat treatment for $30 \mathrm{~min}$ at $100{ }^{\circ} \mathrm{C}$.

$\ddagger$ Samples were taken from 17 dairy farms at geographically diverse locations in Belgium (Scheldeman et al., 2002).

originated from feed concentrate for dairy cattle. Clusters $\mathrm{B}$ and $\mathrm{C}$ each included seven isolates and showed $83 \%$ mutual similarity. Cluster B comprised four feed concentrate isolates and one isolate from raw milk, from the milking apparatus (cluster) and from soy. The seven strains from cluster $\mathrm{C}$ were isolated from the milking equipment [namely, the filter cloth (two strains) and the cluster (two)], from feed concentrate (two) and from raw milk (one). Only two strains occupied distinct positions in the dendrogram, although their profiles closely resembled those of cluster A. R-6521 still showed $87 \%$ similarity to cluster A, whereas R-6952 only showed $79 \%$ similarity to this cluster, probably due to one single additional dense band in the lower molecular mass region (data not shown).

Molecular typing by means of (GTG) $5_{5^{-}}$and REP-PCR revealed respectively four and five groups of profiles among the strains studied (Table 1). The seven strains included in $(\mathrm{GTG})_{5}$ cluster $\mathrm{A}$ corresponded to those included in SDS-PAGE cluster C. The 32 strains in $(G T G)_{5}$ cluster B largely matched those in SDS-PAGE cluster A, with the exception of R-6952, which took a single position in the SDS-PAGE clustering (see above). Although included in SDS-PAGE cluster A, strain R-6685 held a distinct position in the $(\mathrm{GTG})_{5}$ clustering. The five strains included in $(\mathrm{GTG})_{5}$ cluster $\mathrm{C}$ were also included in SDSPAGE cluster B. The two remaining strains of SDS-PAGE cluster B, R-6684 and R-7426, were respectively included in $(\mathrm{GTG})_{5}$ cluster D or distinctly located in the clustering. Strain R-6521, with a separate position in the SDS-PAGE clustering, grouped together with R-6684 in (GTG) cluster D. Finally, R-6685 did not cluster with any of the $(\mathrm{GTG})_{5}$ groups. Numerical analysis of the REP-PCR data revealed five clusters and three separate strains. The 27 and five strains of, respectively, REP clusters A and B corresponded to the 32 strains in $(G T G)_{5}$ cluster $B$, and hence largely to those in SDS-PAGE cluster A. Although REP clusters A and B showed a mutual similarity of only $32 \%$, some common bands in the profiles of these two groups could be observed (data not shown). REP cluster C consisted of five strains, which also grouped together in SDSPAGE cluster B. The two remaining strains in SDS-PAGE cluster B, R-6696 and R-7795, were respectively included in REP cluster D or distinctly located in the dendrogram. Finally, the seven strains included in SDS-PAGE cluster $\mathrm{C}$ and $(\mathrm{GTG})_{5}$ cluster A were grouped together in REP cluster E, except for R-7810, which was grouped in REP cluster D. Overall, there was a good agreement between the three typing methods used, resulting in three groups of strains for which at least two of the three typing techniques supported the overall pattern of the group. Group I comprised 32 isolates corresponding to those in (GTG) $)_{5}$ cluster B, group II of seven isolates comprised all those included in SDS-PAGE cluster B and group III included all isolates of SDS-PAGE cluster C (Table 1). Ultimately, two strains could not be considered to belong to these delineated groups on these criteria and were therefore considered as single strains.

\section{5 rDNA-based phylogeny and DNA-DNA relatedness}

To investigate the taxonomic position of the three groups of strains, 16S rDNA sequence analysis and genomic DNADNA reassociation studies were performed. For the latter study, one representative of each group was included. In addition, the internal relatedness of the large group I was evaluated by including two strains (R-6540 ${ }^{\mathrm{T}}$ and R-8039). A reassociation value of $87 \%$ indicated that $\mathrm{R}-6540^{\mathrm{T}}$ and R-8039 (group I) indeed belong to the same species. The DNA-DNA reassociation values between the representatives of groups I, II and III proved to be low ( $\leqslant 32 \%$; for more details see supplementary table in IJSEM Online). As a result, the three groups delineated on the basis of SDS-PAGE, REP- and (GTG) ${ }_{5}$-PCR can be considered to represent three separate species. The DNA base compositions presented in Table 1 for strains $\mathrm{R}-6540^{\mathrm{T}}$, R-8039, $\mathrm{r}-6514^{\mathrm{T}}$ and $\mathrm{R}-7190^{\mathrm{T}}$ are in accordance with the DNA-DNA 
reassociation values (supplementary table in IJSEM Online). Moreover, the $\mathrm{G}+\mathrm{C}$ value for $\mathrm{R}-6521$ further confirmed its exclusion from groups I and II.

$16 \mathrm{~S}$ rRNA gene sequences for four group I strains (R-6538, $\mathrm{R}-6540^{\mathrm{T}}$, R-6915, R-8039) and strains $\mathrm{R}-6514^{\mathrm{T}}$ and R$7190^{\mathrm{T}}$, representatives of respectively groups II and III, were determined in the present study. The lowest pairwise similarity found within the $16 \mathrm{~S}$ rDNA sequences of the four group I strains was $98 \cdot 8 \%$, for strains $\mathrm{R}-6540^{\mathrm{T}}$ and R-8039. All other values ranged between $99 \cdot 0$ and $99.8 \%$ (data not shown). The $16 \mathrm{~S}$ rDNA sequence similarity of R- $6514^{\mathrm{T}}$ (group II) with the strains from group I ranged from $96.8 \%$ with R-6540 ${ }^{\mathrm{T}}$ to $97 \cdot 5 \%$ with R-6538. For group III strain $\mathrm{R}-7190^{\mathrm{T}}$ a $16 \mathrm{~S}$ rDNA sequence similarity with group I ranging from $95 \cdot 8 \%$ with R-6540 ${ }^{\mathrm{T}}$ to $97 \cdot 1 \%$ with R-6538 was observed. The $16 \mathrm{~S}$ rDNA sequence similarity of R- $6514^{\mathrm{T}}$ and $\mathrm{R}-7190^{\mathrm{T}}$, representing groups II and III, was $97 \cdot 9 \%$. These data indicate the close relationship among the three groups.

The highest similarity found by a FASTA search (Pearson \& Lipman, 1988) for strain $\mathrm{R}-7190^{\mathrm{T}}$ (group III) was $99 \cdot 3 \%$ with the 16S rDNA of Bacillus sp. 112442 JS2 (GenBank accession no. AF071857). The latter strain was isolated from silage after heating samples for $60 \mathrm{~min}$ at $100{ }^{\circ} \mathrm{C}$ (de Silva et al., 1998), also suggesting the possible formation of very heat-resistant spores by this strain. For group I and II strains $\mathrm{R}-6540^{\mathrm{T}}$ and $\mathrm{R}-6514^{\mathrm{T}}$, the FASTA search revealed 96.0 and $99 \cdot 1 \%$ sequence similarity, respectively, with the low $\mathrm{G}+\mathrm{C}$ Gram-positive bacterium M52 (AB116130) isolated from compost. Both strains $\mathrm{R}-6540^{\mathrm{T}}$ and R-6514 ${ }^{\mathrm{T}}$ furthermore showed $95 \cdot 8$ and $98 \cdot 0 \%$ sequence similarity, respectively, with the $16 \mathrm{~S} \mathrm{rDNA}$ of the previously mentioned Bacillus sp. 112442 JS2. The highest $16 \mathrm{~S}$ rDNA sequence similarity with a recognized species found for strain R-6514 ${ }^{\mathrm{T}}$ was only $94.9 \%$ with Bacillus lentus NCIMB $8773^{\mathrm{T}}$ (AB021189) and $94 \cdot 5 \%$ with B. sporothermodurans $\mathrm{M} 215^{\mathrm{T}}$ (U49078). The $16 \mathrm{~S}$ rDNA sequence of strain R-6540 ${ }^{\mathrm{T}}$ showed only $94.5 \%$ similarity with $B$. lentus NCIMB $8773^{\mathrm{T}}$ (AB021189) and $94.5 \%$ with Bacillus galactosidilyticus LMG $17892^{\mathrm{T}}$ (AJ535638). For the $16 \mathrm{~S}$ rDNA sequence of R-7190 , only $94 \cdot 3 \%$ similarity with $B$. lentus NCIMB $8773^{\mathrm{T}}, 94 \cdot 3 \%$ similarity with Bacillus firmus IAM $12464^{\mathrm{T}}$ (D16268) and $94 \cdot 1 \%$ with B. sporothermodurans $\mathrm{M} 215^{\mathrm{T}}$ (U49078) was observed. It can therefore be concluded that groups I, II and III, represented by R- $6540^{\mathrm{T}}$, $\mathrm{R}-6514^{\mathrm{T}}$ and $\mathrm{R}-7190^{\mathrm{T}}$, constitute three novel species within the genus Bacillus. The phylogenetic positions of these three novel species are presented in Fig. 1, by means of a neighbour-joining tree with a selection of recognized Bacillus species. All groups (I, II and III) were clearly separated from the other Bacillus species included. The four strains comprising group I clearly appeared as a well-separated branch in the phylogenetic tree, whereas $\mathrm{R}-7190^{\mathrm{T}}$ showed a high relatedness to Bacillus sp. 112442 JS2, as discussed above. Group II strain R-6514 ${ }^{\mathrm{T}}$ was located in the same deeper branching group.

\section{Standard bacteriological characterization and fatty acid composition}

All strains were unreactive in the API 20E and 50CHB tests. In the API Biotype100 tests all strains did react, and some characters that differentiated the three groups were observed (Table 2). Most of the group I strains showed a reactive and consistent profile in which amino acids and organic acids were utilized as sole carbon and energy sources, but very few carbohydrates were assimilated. Members of groups II and III also attacked amino acids and organic acids and very few carbohydrates, but their ranges of substrates utilized were narrower than for group I strains, their reactions were weaker and considerable between-strain variation was observed. As the three novel

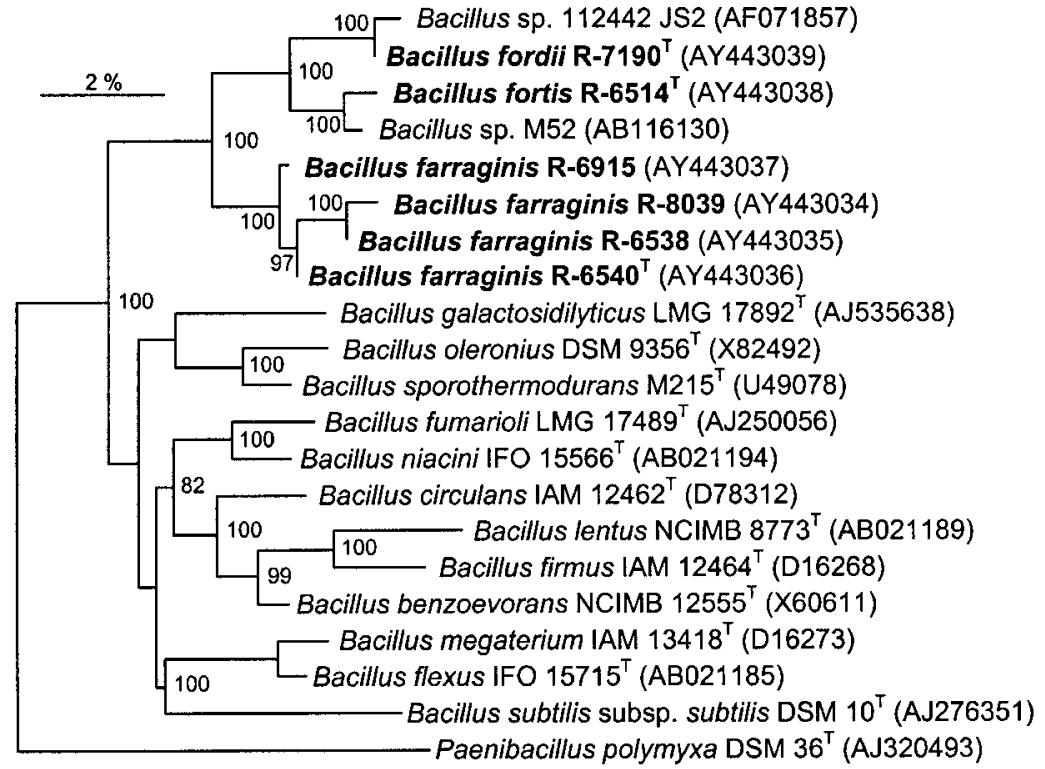

Fig. 1. Neighbour-joining tree derived from $16 S$ rDNA sequences, showing the phylogenetic positions of Bacillus farraginis sp. nov., Bacillus fortis sp. nov. and Bacillus fordii sp. nov. strains and the type strains of the most closely related Bacillus species. GenBank accession numbers are given and bootstrap values (expressed as percentages of 1000 replications) are shown at branch points when higher than $70 \%$. Unknown bases were not considered for the analysis. 
Table 2. Phenotypic characteristics that distinguish $B$. farraginis sp. nov., B. fortis sp. nov. and $B$. fordii sp. nov. in the Biotype100 system

Unless otherwise indicated, characters refer to the use of different compounds as sole carbon sources in the Biotype100 system. +, Positive; -, negative; V, variable among strains; $\mathrm{W}$, weak for all strains tested; $n$, number of strains analysed.

\begin{tabular}{|lccc|}
\hline Character & $\begin{array}{c}\text { Group I } \\
\text { B. farraginis }(\boldsymbol{n}=\mathbf{2 9})\end{array}$ & $\begin{array}{c}\text { Group II } \\
\text { B. fortis }(\boldsymbol{n}=\mathbf{6})\end{array}$ & $\begin{array}{c}\text { Group III } \\
\text { B. } \text { fordii }(\boldsymbol{n}=7)\end{array}$ \\
\hline Production of pigment in casein & - & - & + \\
Growth at pH 5 & - & - & + \\
D-Alanine & + & - & - \\
L-Alanine & + & - & $\mathrm{V}$ \\
4-Aminobutyrate & + & $\mathrm{V}$ & - \\
Fumarate & + & - & $\mathrm{V}$ \\
L-Glutamate & + & $\mathrm{V}$ & - \\
3-Hydroxybutyrate & + & - & $\mathrm{V}$ \\
L-Malate & + & $\mathrm{V}$ & - \\
Methyl $\alpha$-galactopyranoside & - & - & $\mathrm{W}$ \\
Methyl $\beta$-galactopyranoside & $\mathrm{V}$ & - & $\mathrm{W}$ \\
3-Methyl D-glucopyranose & - & - & $\mathrm{W}$ \\
Methyl $\alpha$-D-glucopyranoside & $\mathrm{V}$ & - & $\mathrm{W}$ \\
L-Proline & + & $\mathrm{V}$ & - \\
Succinate & + & - & $\mathrm{V}$ \\
\hline
\end{tabular}

species are unreactive in the API $20 \mathrm{E}$ and 50CHB kits, this distinguishes them from their closest phylogenetic neighbours (e.g. B. lentus), and so a more extended diagnostic table is of no informative or practical value.

All strains were found to be Gram-negative, aerobic, motile rods, which formed ellipsoidal spores positioned paracentrally to subterminally (groups I and III) or centrally to paracentrally (group II). Photomicrographs of cells and spores for the three species are available as supplementary material in IJSEM Online. In a cluster analysis (data not shown) based on similarities calculated from both positively and negatively matching Biotype100 data, all but two of the 29 strains forming group I merged at $82.5 \% S_{\mathrm{G}}$ and joined with clusters containing the remaining two group I strains and all of the group II and III strains at only $75 \%$. Such relatively low percentage similarities are typical of Biotype100 data with similarities calculated using $S_{\mathrm{G}}$ (Logan et al., 2002). Strains forming group II merged at $90 \% S_{\mathrm{G}}$, but this cluster contained one of the atypical group I strains (R-7351), and the other atypical group I strain (R-6952) joined this cluster at $87.5 \% S_{\mathrm{G}}$. These atypical strains could be recognized as members of group I on the basis of molecular data, but their phenotypic profiles were narrower and weaker than the other group I strains. Strain R-6952, however, was also found to be atypical in its whole-cell protein profile. Strains belonging to group III showed even greater within-group variation and all but one of the strains (R-7810) formed two subclusters at $90 \%$; one of these subclusters merged with group II at $85 \%$ and the other, along with the remaining ungrouped strain (R-7810), joined at only $82.5 \%$. The atypical group III strain R-7810 also showed a different REP pattern to other members of this group.

The mean fatty acid profiles for the Bacillus strains examined are listed in Table 3. A predominance of iso- $\mathrm{C}_{15: 0}$ could be observed for each novel species. Group I strains could be differentiated from group II and III by means of a larger amount of the branched fatty acids anteiso- $\mathrm{C}_{15: 0}$ and anteiso- $\mathrm{C}_{17: 0}$ on the one hand and a smaller amount of the saturated fatty acids $\mathrm{C}_{14: 0}$ and $\mathrm{C}_{16: 0}$ on the other hand. Discrimination between group II and groups I and III was possible based on a larger amount of the saturated fatty acids $C_{15: 0}$ and $C_{17: 0}$ for group II strains. Finally, group III strains could be distinguished from groups I and II on the basis of a larger amount of the unsaturated fatty acids $\mathrm{C}_{16: 1} \omega 11 c$ and $\mathrm{C}_{18: 1} \omega 9 c$ and the branched fatty acids iso$\mathrm{C}_{17: 0}$ and iso- $\mathrm{C}_{17: 0} \omega 10 c$. These data are in accordance with the previous findings that groups I, II and III represent separate novel species within the genus Bacillus.

\section{Conclusions}

Combining all of the genotypic and phenotypic data presented here, it is clear that the 48 isolates form three homogeneous groups that are clearly different from all other related species within the genus Bacillus. Therefore, they represent three novel species of the genus Bacillus, for which we propose the names Bacillus farraginis sp. nov., Bacillus fortis sp. nov. and Bacillus fordii sp. nov. All strains of these novel species were isolated after heat treatment of $30 \mathrm{~min}$ at $100^{\circ} \mathrm{C}$, suggesting that these strains might be capable of forming very heat-resistant endospores. Further research is needed to reveal to what extent the spores of these 
Table 3. Cellular fatty acid composition of the three novel Bacillus species isolated at dairy farms Values are percentages of total fatty acids expressed as means \pm SD for the number of strains analysed. ND, Not detected.

\begin{tabular}{|c|c|c|c|}
\hline Fatty acid & $\begin{array}{c}\text { Group I } \\
\text { B. farraginis }(n=17)\end{array}$ & $\begin{array}{l}\text { Group II } \\
\text { B. fortis }(n=7)\end{array}$ & $\begin{array}{l}\text { Group III } \\
\text { B. fordii }(n=7)\end{array}$ \\
\hline \multicolumn{4}{|l|}{ Saturated fatty acids: } \\
\hline $\mathrm{C}_{14: 0}$ & $0 \cdot 3 \pm 0 \cdot 4$ & $1 \cdot 4 \pm 0 \cdot 2$ & $1 \cdot 6 \pm 0 \cdot 5$ \\
\hline $\mathrm{C}_{15: 0}$ & $1 \cdot 7 \pm 1 \cdot 6$ & $5 \cdot 9 \pm 2 \cdot 0$ & $1 \cdot 9 \pm 0 \cdot 6$ \\
\hline $\mathrm{C}_{16: 0}$ & $1 \cdot 1 \pm 0 \cdot 6$ & $3 \cdot 5 \pm 0 \cdot 6$ & $3 \cdot 0 \pm 0 \cdot 8$ \\
\hline $\mathrm{C}_{17: 0}$ & $\mathrm{ND}$ & $2 \cdot 0 \pm 0 \cdot 5$ & $0 \cdot 9 \pm 0 \cdot 2$ \\
\hline $\mathrm{C}_{18: 0}$ & $<0 \cdot 2^{\star}$ & $<0 \cdot 2^{\star}$ & $0 \cdot 3 \pm 0 \cdot 3$ \\
\hline \multicolumn{4}{|c|}{ Unsaturated fatty acids: } \\
\hline $\mathrm{C}_{16: 1} \omega 7 c$ alcohol & $5 \cdot 3 \pm 2 \cdot 0$ & $3 \cdot 8 \pm 0 \cdot 6$ & $2 \cdot 9 \pm 0 \cdot 5$ \\
\hline $\mathrm{C}_{16: 1} \omega 11 c$ & $3 \cdot 0 \pm 0 \cdot 7$ & $4 \cdot 2 \pm 0 \cdot 6$ & $6 \cdot 4 \pm 0 \cdot 8$ \\
\hline $\mathrm{C}_{18: 1} \omega 7 c$ & $\mathrm{ND}$ & $\mathrm{ND}$ & $<0 \cdot 2 \dagger$ \\
\hline $\mathrm{C}_{18: 1} \omega 9 c$ & $\mathrm{ND}$ & $<0 \cdot 1 \ddagger$ & $1 \cdot 1 \pm 0 \cdot 2$ \\
\hline \multicolumn{4}{|l|}{ Branched fatty acids: } \\
\hline iso- $\mathrm{C}_{13: 0}$ & ND & ND & $<0 \cdot 2 \dagger$ \\
\hline iso- $\mathrm{C}_{14: 0}$ & $3 \cdot 3 \pm 2 \cdot 5$ & $5 \cdot 3 \pm 1 \cdot 4$ & $2 \cdot 5 \pm 0 \cdot 5$ \\
\hline iso- $\mathrm{C}_{15: 0}$ & $36 \cdot 4 \pm 8 \cdot 2$ & $34 \cdot 9 \pm 2 \cdot 8$ & $42 \cdot 0 \pm 2 \cdot 9$ \\
\hline iso- $\mathrm{C}_{16: 0}$ & $6 \cdot 4 \pm 4 \cdot 3$ & $9 \cdot 9 \pm 2 \cdot 0$ & $4 \cdot 3 \pm 0 \cdot 6$ \\
\hline iso- $\mathrm{C}_{17: 0}$ & $3 \cdot 4 \pm 1 \cdot 0$ & $3 \cdot 2 \pm 0 \cdot 6$ & $5 \cdot 9 \pm 1 \cdot 0$ \\
\hline anteiso- $\mathrm{C}_{15: 0}$ & $26 \cdot 7 \pm 4 \cdot 0$ & $19 \cdot 2 \pm 1 \cdot 9$ & $18 \cdot 0 \pm 1 \cdot 9$ \\
\hline anteiso- $\mathrm{C}_{17: 0}$ & $11 \cdot 0 \pm 1 \cdot 8$ & $5 \cdot 7 \pm 1 \cdot 2$ & $6 \cdot 7 \pm 1 \cdot 7$ \\
\hline iso- $\mathrm{C}_{17: 0} \omega 10 c$ & $0 \cdot 3 \pm 0 \cdot 6$ & $0 \cdot 3 \pm 0 \cdot 4$ & $1 \cdot 6 \pm 0 \cdot 4$ \\
\hline anteiso- $\mathrm{C}_{17: 1} \omega 9 c$ & $\mathrm{ND}$ & $\mathrm{ND}$ & $<0 \cdot 2 \dagger$ \\
\hline Summed feature $3 \$$ & $\mathrm{ND}$ & ND & $0 \cdot 3 \pm 0 \cdot 7 \dagger$ \\
\hline Summed feature $4 \S$ & $1 \cdot 2 \pm 0 \cdot 7$ & $0.6 \pm 0.5$ & $0 \cdot 4 \pm 0 \cdot 4$ \\
\hline
\end{tabular}

${ }^{*} \mathrm{C}_{18: 0}$ was detected only in strains R-6932 (B. farraginis) and R-7795 (B. fortis), at less than $1 \%$.

$\dagger \mathrm{C}_{18: 1} \omega 7 c$, iso- $\mathrm{C}_{13: 0}$, anteiso- $\mathrm{C}_{17: 1} \omega 9 c$ and summed feature 3 were detected only in strain R-7810, at low levels (respectively $1 \cdot 0,0 \cdot 4,0 \cdot 8$ and $1 \cdot 8 \%$ ).

$\ddagger \mathrm{C}_{18: 1} \omega 9 \mathrm{c}$ was detected only in strain R-6514, at less than $1 \%$.

$\S$ Summed feature 3 represents $\mathrm{C}_{15: 0} 2 \mathrm{OH}$ and/or $\mathrm{C}_{16: 1} \omega 7 c$, which could not be separated by GLC using the MIDI system. Summed feature 4 similarly represents iso- $\mathrm{C}_{17: 1} \mathrm{I}$ and/or anteiso- $\mathrm{C}_{17: 1} \mathrm{~B}$.

strains can be highly heat resistant and as a result adversely affect the quality of heat-treated dairy products.

\section{Description of Bacillus farraginis sp. nov.}

Bacillus farraginis (far.ra.gin'is. L. gen. fem. n. farraginis from mixed fodder for cattle, referring to feed concentrate for dairy cattle as the principal isolation source).

Cells are long, straight, round-ended, motile, strictly aerobic, Gram-negative rods, occurring singly, in pairs or filaments. Cell diameter is $0 \cdot 5-0.8 \mu \mathrm{m}$ and cell length $1 \cdot 2-4 \mu \mathrm{m}$. Spores are ellipsoidal and occur paracentrally or subterminally in occasionally slightly swollen sporangia. Colonies grown for 3 days at $30^{\circ} \mathrm{C}$ on nutrient agar are cream coloured or translucent, slightly raised, with irregular margins and granular, glossy surfaces. Colony diameter is no greater than $1 \mathrm{~mm}$. Good growth occurs at 30 and $45^{\circ} \mathrm{C}$ and weak growth occurs at $20^{\circ} \mathrm{C}$. Some strains are capable of growth at $\mathrm{pH} 9$ but none grows at $\mathrm{pH}$ 5. Growth is not inhibited by $7 \%(\mathrm{w} / \mathrm{v}) \mathrm{NaCl}$. Hydrolysis of starch and casein is not observed within 7 days of incubation at $30{ }^{\circ} \mathrm{C}$, and growth in casein agar is poor or negative. Catalase and oxidase are positive. All strains are unreactive in the API 20E and API 50CHB test kits. In the Biotype100 kit using the Biotype 2 medium, nearly all strains (>83\%) belonging to the species are able to use the following substrates as sole carbon sources: 4-aminobutyrate, 5aminovalerate, D- and L-alanine, fumarate, L-glutamate, glutarate, L-histidine, 3-hydroxybutyrate, 2-oxoglutarate, D- and L-malate, DL-lactate, L-proline, putrescine, succinate, L-tryptophan and L-tyrosine. Many strains $(>45 \%)$ are able to use L-aspartate, dulcitol, $m$-hydroxybenzoate, malonate, D-mannitol, D-ribose and D-sorbitol. Other substrates are used less frequently (17-44\%): L-arabinose, D-galactose, gentisate, D-glucuronate, $p$-hydroxybenzoate, myo-inositol and $\alpha$-L-rhamnose. The following substrates are seldom or 
never used as sole carbon sources: cis- and trans-aconitate, adonitol, D- and L-arabitol, benzoate, betaine, caprate, caprylate, D-cellobiose, citrate, $m$-coumarate, erythritol, aesculin, ethanolamine, $\beta$-D-fructose, $\alpha$-L-fucose, D-galacturonate, $\beta$-gentiobiose, D-gluconate, D-glucosamine, $\alpha$-D-glucose, DL-glycerate, glycerol, histamine, hydroxyquinoline $\beta$-glucuronide, itaconate, 2 - and 5-keto-D-gluconate, $\alpha$-lactose, lactulose, D-lyxose, maltitol, maltose, maltotriose, D-mannose, $\alpha$-D-melibiose, D-melezitose, methyl $\alpha$ galactopyranoside, methyl $\beta$-galactopyranoside, 3-methyl D-glucopyranose, methyl $\alpha$-D-glucopyranoside, methyl $\beta$-Dglucopyranoside, mucate, $\mathrm{N}$-acetyl D-glucosamine, palatinose, phenylacetate, 3-phenylpropionate, propionate, protocatechuate, quinate, D-raffinose, D-saccharate, sucrose, L-serine, L-sorbose, D-tagatose, L-, meso- and D-tartrate, D-trehalose, D-turanose, tricarballylate, trigonelline, tryptamine, D-xylose and xylitol.

The type strain, R- $6540^{\mathrm{T}}\left(=\mathrm{MB} 1885^{\mathrm{T}}=\mathrm{LMG} 22081^{\mathrm{T}}=\right.$ DSM $16013^{\mathrm{T}}$ ), utilizes the following substrates as sole carbon sources: 4-aminobutyrate, 5-aminovalerate, D- and L-alanine, L-aspartate, dulcitol, fumarate, D-glucosamine, L-glutamate, glutarate, histamine, L-histidine, $m$-hydroxybenzoate, 3-hydroxybutyrate, 2-oxoglutarate, $D$ - and L-malate, malonate, DL-lactate, L-proline, putrescine, Dribose, D-sorbitol, succinate, meso-tartrate, L-tryptophan and L-tyrosine. The major cellular fatty acids $(>5 \%$ of total cellular fatty acids) are iso- $\mathrm{C}_{15: 0}$, anteiso- $\mathrm{C}_{15: 0}$, anteiso- $\mathrm{C}_{17: 0}$, iso- $\mathrm{C}_{16: 0}$ and $\mathrm{C}_{16: 1} \omega 7 c$ alcohol. The DNA $\mathrm{G}+\mathrm{C}$ composition of the type strain is $43 \cdot 7 \mathrm{~mol} \%$.

\section{Description of Bacillus fortis sp. nov.}

Bacillus fortis (for'tis. L. adj. fortis strong, referring to the fact that the strains were isolated after heat treatment for $30 \mathrm{~min}$ at $100^{\circ} \mathrm{C}$ ).

Cells are straight, round-ended, motile, strictly aerobic, Gram-negative rods, occurring singly or in pairs. Cell diameter is $0.6-0.8 \mu \mathrm{m}$ and length $1 \cdot 0-3.5 \mu \mathrm{m}$. Spores are oval and occur centrally or paracentrally in slightly swollen sporangia. Colonies grown on nutrient agar at $30^{\circ} \mathrm{C}$ for 3 days are cream coloured, raised with entire margins and smooth, glossy surfaces. Their maximum diameter is $1 \mathrm{~mm}$. Good growth occurs at 30 and $45^{\circ} \mathrm{C}$ and weak growth occurs at $20^{\circ} \mathrm{C}$. Growth does not occur at $\mathrm{pH} 9$ or 5 . Growth is not inhibited by $7 \%(\mathrm{w} / \mathrm{v}) \mathrm{NaCl}$. Hydrolysis of starch and casein is not observed within 7 days of incubation at $30^{\circ} \mathrm{C}$, and growth on casein agar is poor or negative. Catalase and oxidase are positive. All strains are unreactive in the API 20E and API 50CHB test kits. In the Biotype100 kit using the Biotype 2 medium, strains use L-tryptophan and L-histidine as sole carbon sources. Most strains (>50\%) use the following substrates as sole carbon sources: 4-aminobutyrate, 5-aminovalerate, aesculin, ethanolamine, glutarate, hydroxyquinoline $\beta$-glucuronide, 2 -oxoglutarate, DL-lactate, malonate, phenylacetate, L-proline, putrescine, D-ribose and L-tyrosine. Some strains $(<50 \%)$ use the following substrates: citrate, erythritol, D-gluconate,
D-glucosamine, $\alpha$-D-glucose, L-glutamate, DL-glycerate, histamine, $m$-hydroxybenzoate, 2 - and 5-keto-D-gluconate, L- and D-malate, $\alpha$-D-melibiose, protocatechuate, L-sorbose and L-tartrate. Only the type strain uses D-glucuronate and no strain utilizes the following substrates as sole carbon sources: trans- and cis-aconitate, adonitol, D- and L-alanine, L-arabinose, D- and L-arabitol, L-aspartate, betaine, benzoate, caprate, caprylate, $\mathrm{D}$-cellobiose, $m$-coumarate, dulcitol, $\beta$-D-fructose, $\alpha$-L-fucose, fumarate, D-galactose, D-galacturonate, $\beta$-gentiobiose, gentisate, glycerol, $p$ hydroxybenzoate, 3-hydroxybutyrate, myo-inositol, itaconate, $\alpha$-lactose, lactulose, D-lyxose, maltitol, maltose, maltotriose, D-mannitol, D-mannose, D-melezitose, methyl $\alpha$-galactopyranoside, methyl $\beta$-galactopyranoside, 3-methyl D-glucopyranose, methyl $\alpha$-D-glucopyranoside, methyl $\beta$-Dglucopyranoside, mucate, $\mathrm{N}$-acetyl D-glucosamine, palatinose, 3-phenylpropionate, propionate, quinate, D-raffinose, $\alpha$-L-rhamnose, D-saccharate, sucrose, L-serine, D-sorbitol, succinate, D-tagatose, D- and meso-tartrate, D-trehalose, tricarballylate, trigonelline, tryptamine, D-turanose, xylitol and D-xylose.

The type strain is R- $6514^{\mathrm{T}}\left(=\mathrm{LMG} 22079^{\mathrm{T}}=\mathrm{DSM} 16012^{\mathrm{T}}\right)$. Where results are variable, the type strain uses the following substrates: aesculin, D-gluconate, D-glucosamine, D-glucuronate, DL-glycerate, hydroxyquinoline- $\beta$-glucuronide, 2-oxoglutarate, 2 - and 5-keto-D-gluconate, DL-lactate, malonate, phenylacetate, protocatechuate, L-tartrate and L-tyrosine. The major cellular fatty acids ( $>5 \%$ of total cellular fatty acids) are iso- $\mathrm{C}_{15: 0}$, anteiso- $\mathrm{C}_{15: 0}$, iso- $\mathrm{C}_{16: 0}$, $\mathrm{C}_{15: 0}$ and anteiso- $\mathrm{C}_{17: 0}$. The DNA G+C content of the type strain is $44 \cdot 3 \mathrm{~mol} \%$.

\section{Description of Bacillus fordii sp. nov.}

Bacillus fordii (for' di.i. N.L. gen. n. fordii named after W. W. Ford, an American microbiologist working on aerobic spore-forming bacteria at the beginning of the twentieth century).

Cells are long, straight, round-ended, motile, strictly aerobic, Gram-negative rods, occurring singly or in pairs. Cell diameter is $0 \cdot 6-0 \cdot 8 \mu \mathrm{m}$ and length $1 \cdot 6-3 \cdot 5 \mu \mathrm{m}$. Spores are ellipsoidal and occur paracentrally or subterminally in, occasionally, slightly swollen sporangia. Colonies grown on nutrient agar at $30^{\circ} \mathrm{C}$ for 3 days are cream coloured, raised, with entire margins and smooth glossy surfaces. Their maximum diameter is $2 \mathrm{~mm}$. Good growth occurs at 30 and $45^{\circ} \mathrm{C}$ and weak growth occurs at $20^{\circ} \mathrm{C}$. Growth occurs at $\mathrm{pH} 9$ and some strains grow at $\mathrm{pH}$ 5. Growth is not inhibited by $7 \%(\mathrm{w} / \mathrm{v}) \mathrm{NaCl}$. Hydrolysis of starch and casein is not observed within 7 days of incubation at $30^{\circ} \mathrm{C}$. Growth on casein agar is coloured faint pink. Catalase and oxidase are positive. All strains are unreactive in the API 20E and API 50CHB test kits. In the Biotype100 kit using the Biotype 2 medium, all strains show very good production of biomass using malonate and L-tyrosine as sole carbon sources. Variable results with good production of biomass are obtained for L-histidine, 2-oxoglutarate, 
glutarate, DL-lactate, 5-aminovalerate and L-tryptophan. All or most strains are capable of weak growth from the following carbon sources: aesculin, gentisate, protocatechuate, meso-tartrate, D-glucosamine, DL-glycerate, quinate, ethanolamine, D-glucuronate, $p$-hydroxybenzoate, hydroxyquinoline $\beta$-glucuronide and 2 - and 5-keto-D-gluconate. Growth occurs seldom and weakly from the following substrates: adonitol, L-alanine, L-arabinose, L-arabitol, benzoate, fumarate, D-galacturonate, D-gluconate, $\alpha$-Dglucose, histamine, 3-hydroxybutyrate, D-lyxose, D-malate, methyl $\alpha$-galactopyranoside, methyl $\beta$-D-glucopyranoside, $N$-acetyl D-glucosamine, phenylacetate, propionate, putrescine, D-raffinose, D-ribose, D-saccharate, L-sorbose, succinate, D-tagatose, L-tartrate, tricarballylate, trigonelline and D-xylose. The following substrates are not used as sole carbon source: cis- and trans-aconitate, D-alanine, 4-aminobutyrate, D-arabitol, L-aspartate, betaine, caprate, caprylate, D-cellobiose, citrate, $m$-coumarate, dulcitol, erythritol, $\beta$-D-fructose, $\alpha$-L-fucose, $\mathrm{D}$-galactose, $\beta$-gentiobiose, L-glutamate, glycerol, $m$-hydroxybenzoate, myoinositol, itaconate, $\alpha$-lactose, lactulose, L-malate, maltitol, maltose, maltotriose, D-mannitol, D-mannose, $\alpha$-Dmelibiose, D-melezitose, methyl $\beta$-galactopyranoside, 3 methyl D-glucopyranoside, methyl $\alpha$-D-glucopyranoside, mucate, palatinose, 3-phenylpropionate, L-proline, $\alpha$-Lrhamnose, sucrose, L-serine, D-sorbitol, D-tartrate, D-trehalose, tryptamine, D-turanose and xylitol.

The type strain is $\mathrm{R}-7190^{\mathrm{T}}\left(=\mathrm{MB} 1878^{\mathrm{T}}=\mathrm{LMG} 22080^{\mathrm{T}}=\right.$ DSM $16014^{\mathrm{T}}$ ). Where results are variable, the type strain uses the following substrates: aesculin, 5-aminovalerate, L-arabinose, benzoate, ethanolamine, D-galacturonate, gentisate, D-glucuronate, glutarate, DL-glycerate, histamine, p-hydroxybenzoate, 3-hydroxybutyrate, hydroxyquinoline$\beta$-glucuronide, 2- and 5-keto-D-gluconate, 2-oxoglutarate, DL-lactate, D-lyxose, $N$-acetyl D-glucosamine, phenylacetate, protocatechuate, putrescine, quinate, D-raffinose, mesotartrate, tricarballylate, L-tryptophan and D-xylose. The major cellular fatty acids ( $>5 \%$ of total cellular fatty acids) are iso- $\mathrm{C}_{15: 0}$, anteiso- $\mathrm{C}_{15: 0}$, anteiso- $\mathrm{C}_{17: 0}, \mathrm{C}_{16: 1} \omega 11 \mathrm{c}$ and iso- $\mathrm{C}_{17: 0}$. The DNA $\mathrm{G}+\mathrm{C}$ content of the type strain is $41 \cdot 9 \mathrm{~mol} \%$.

\section{ACKNOWLEDGEMENTS}

We wish to thank P. Vanmol, L. Lebbe, S. Cots-Gilloway and E. Engels for excellent technical assistance. We are most grateful to bioMérieux S.A. for providing API materials and for supporting M. R.-D. P.D. V. is indebted to the National Fund for Scientific Research (Belgium) for financial support by grant G.0156.02.

\section{REFERENCES}

Coenye, T., Falsen, E., Vancanneyt, M., Hoste, B., Govan, J. R. W., Kersters, K. \& Vandamme, P. (1999). Classification of Alcaligenes faecalis-like isolates from the environment and human clinical samples as Ralstonia gilardii sp. nov. Int J Syst Bacteriol 49, 405-413.

Crielly, E. M., Logan, N. A. \& Anderton, A. (1994). Studies on the Bacillus flora of milk and milk products. J Appl Bacteriol 77, 256-263.
De Clerck, E., Rodríguez-Díaz, M., Vanhoutte, T., Heyrman, J., Logan, N. A. \& De Vos, P. (2004). Anoxybacillus contaminans sp. nov. and Bacillus gelatini sp. nov., isolated from contaminated gelatin batches. Int J Syst Evol Microbiol 54, 941-946.

de Silva, S., Pettersson, B., Aquino de Muro, M. A. \& Priest, F. G. (1998). A DNA probe for the detection and identification of Bacillus sporothermodurans using the 16S-23S rDNA spacer region and phylogenetic analysis of some field isolates of Bacillus which form highly heat resistant spores. Syst Appl Microbiol 21, 398-407.

Ezaki, T., Hashimoto, Y. \& Yabuuchi, E. (1989). Fluorometric deoxyribonucleic acid-deoxyribonucleic acid hybridization in microdilution wells as an alternative to membrane-filter hybridization in which radioisotopes are used to determine genetic relatedness among bacterial strains. Int J Syst Bacteriol 39, 224-229.

Gevers, D., Huys, G. \& Swings, J. (2001). Applicability of rep-PCR fingerprinting for identification of Lactobacillus species. FEMS Microbiol Lett 205, 31-36.

Griffiths, M. W. \& Philips, J. D. (1990). Incidence, source and some properties of psychrotrophic Bacillus spp. found in raw and pasteurised milk. J Soc Dairy Tech 43, 62-66.

Guillaume-Gentil, O., Scheldeman, P., Marugg, J., Herman, L., Joosten, H. \& Heyndrickx, M. (2002). Genetic heterogeneity in Bacillus sporothermodurans as demonstrated by ribotyping and repetitive extragenic palindromic-PCR fingerprinting. Appl Environ Microbiol 68, 4216-4224.

Guirguis, A. H., Griffiths, M. W. \& Muir, D. D. (1983). Sporeforming bacteria in milk. 1. Optimisation of heat treatment for activation of spores of Bacillus species. Milchwissenschaft 38, 641-644.

Hammer, P., Lembke, F., Suhren, G. \& Heeschen, W. (1995). Characterization of a heat resistant mesophilic Bacillus species affecting quality of UHT-milk - a preliminary report. Kiel Milchwirtsch Forschungsber 47, 303-311.

Herman, L., Heyndrickx, M. \& Waes, G. (1998). Typing of Bacillus sporothermodurans and other Bacillus species isolated from milk by repetitive element sequence based PCR. Lett Appl Microbiol 26, 183-188.

Heyndrickx, M., Lebbe, L., Vancanneyt, M. \& 7 other authors (1997). A polyphasic reassessment of the genus Aneurinibacillus, reclassification of Bacillus thermoaerophilus (Meier-Stauffer et al. 1996) as Aneurinibacillus thermoaerophilus comb. nov., and $A$. migulanus, and A. thermoaerophilus. Int J Syst Bacteriol 47, 808-817.

Heyrman, J., Vanparys, B., Logan, N. A., Balcaen, A., RodríguezDíaz, M., Felske, A. \& De Vos, P. (2004). Bacillus novalis sp. nov., Bacillus vireti sp. nov., Bacillus soli sp. nov., Bacillus bataviensis sp. nov. and Bacillus drentensis sp. nov., from the Drentse A grasslands. Int J Syst Evol Microbiol 54, 47-57.

Logan, N. A. \& Berkeley, R. C. W. (1984). Identification of Bacillus strains using the API system. J Gen Microbiol 130, 1871-1882.

Logan, N. A., Lebbe, L., Hoste, B. \& 7 other authors (2000). Aerobic endospore-forming bacteria from geothermal environments in northern Victoria Land, Antarctica, and Candlemas Island, South Sandwich archipelago, with the proposal of Bacillus fumarioli sp. nov. Int J Syst Evol Microbiol 50, 1741-1753.

Logan, N. A., Forsyth, G., Lebbe, L. \& 8 other authors (2002). Polyphasic identification of Bacillus and Brevibacillus strains from clinical, dairy and industrial specimens and proposal of Brevibacillus invocatus sp. nov. Int J Syst Evol Microbiol 52, 953-966.

McGuiggan, J. T. M., McCleery, D. R., Hannan, A. \& Gilmour, A. (2002). Aerobic spore-forming bacteria in bulk raw milk: factors influencing the numbers of psychrotrophic, mesophilic and thermophilic Bacillus spores. Int J Dairy Technol 55, 100-107. 
Meer, R. R., Baker, J., Bodyfelt, F. W. \& Griffiths, M. W. (1991). Psychrotrophic Bacillus spp. in fluid milk products: a review. J Food Prot 54, 969-979.

Pearson, W. R. \& Lipman, D. J. (1988). Improved tools for biological sequence comparison. Proc Natl Acad Sci U $S$ A 85, 2444-2448.

Pitcher, D. G., Saunders, N. A. \& Owen, R. J. (1989). Rapid extraction of bacterial genomic DNA with guanidium thiocyanate. Lett Appl Microbiol 8, 151-156.

Pot, B., Vandamme, P. \& Kersters, K. (1994). Analysis of electrophoretic whole organism protein fingerprints. In Chemical Methods in Prokaryotic Systematics, pp. 493-521. Edited by M. Goodfellow \& A. G. O'Donnell. Chichester: Wiley.

Scheldeman, P., Herman, L., Goris, J., De Vos, P. \& Heyndrickx, M. (2002). Polymerase chain reaction identification of Bacillus sporothermodurans from dairy sources. J Appl Microbiol 92, 983-991.

Ternström, A., Lindberg, A.-M. \& Molin, G. (1993). Classification of the spoilage flora of raw and pasteurised bovine milk, with special reference to Pseudomonas and Bacillus. J Appl Bacteriol 75, $25-34$.
Vaerewijck, M. J., De Vos, P., Lebbe, L., Scheldeman, P., Hoste, B. \& Heyndrickx, M. (2001). Occurrence of Bacillus sporothermodurans and other aerobic spore-forming species in feed concentrate for dairy cattle. J Appl Microbiol 91, 1074-1084.

Vancanneyt, M., Witt, S., Abraham, W. R., Kersters, K. \& Fredrickson, H. L. (1996). Fatty acid content in whole-cell hydrolysates and phospholipid fractions of pseudomonads: a taxonomic evaluation. Syst Appl Microbiol 19, 528-540.

Vauterin, L. \& Vauterin, P. (1992). Computer aided objective comparison of electrophoretic patterns for grouping and identification of microorganisms. Eur Microbiol 1, 37-41.

Versalovic, J., Schneider, M., de Bruijn, F. J. \& Lupski, J. R. (1994). Genomic fingerprinting of bacteria using repetitive sequence-based polymerase chain reaction. Methods Mol Cell Biol 5, 25-40.

Waes, G. (1976). Aerobic mesophilic spores in raw milk. Milchwissenschaft 31, 521-525.

Willems, A., Doignon-Bourcier, F., Goris, J., Coopman, R., de Lajudie, P., De Vos, P. \& Gillis, M. (2001). DNA-DNA hybridization study of Bradyrhizobium strains. Int $J$ Syst Evol Microbiol 51, 1315-1322. 